\title{
Patriarchy and Women's Subordination: A Theoretical Analysis
}

\begin{abstract}
Abeda Sultana, $P h D^{*}$
Introduction

Patriarchy is the prime obstacle to women's advancement and development. Despite differences in levels of domination the broad principles remain the same, i.e. men are in control. The nature of this control may differ. So it is necessary to understand the system, which keeps women dominated and subordinate, and to unravel its workings in order to work for women's development in a systematic way. In the modern world where women go ahead by their merit, patriarchy there creates obstacles for women to go forward in society. Because patriarchal institutions and social relations are responsible for the inferior or secondary status of women. Patriarchal society gives absolute priority to men and to some extent limits women's human rights also. Patriarchy refers to the male domination both in public and private spheres. In this way, feminists use the term 'patriarchy' to describe the power relationship between men and women as well as to find out the root cause of women's subordination. This article, hence, is an attempt to analyse the concept of patriarchy and women's subordination in a theoretical perspective.
\end{abstract}

\section{The Objective of the Study and Procedure}

Modern civilization is the result of joint action of men and women. No nation can progress without the help of women. Now a days women are seen in positions of power. There are queens and prime ministers with constitutional control or virtual, and women in general have wrested benefits in greater or smaller measures. But all

\footnotetext{
${ }^{*}$ Associate Professor, Department of Political Science, University of Dhaka
} 
this does not change the fact that the system is male dominated and women are merely accommodated in it in a variety of ways. So the main purpose of the study is to analyse patriarchy and women's subordination. The paper consists of four sections. The first section defines the key concept of 'patriarchy' with its origin. The second section deals with women's subordination and factors that men control in a patriarchal system, in other words, how patriarchy benefits men materially. The third section examines the patriarchal structures of Bangladesh and how this system undermines women's position. Finally, some suggestions have been forwarded to raise women's position in the society. Concluding remarks are included in this section. This article is written entirely on the basis of secondary sources that include review of books, journals, proceedings of seminars and other secondary materials.

\section{Concept of Patriarchy}

The word 'patriarchy' literally means the rule of the father or the 'patriarch', and originally it was used to describe a specific type of 'male-dominated family' - the large household of the patriarch which included women, junior men, children, slaves and domestic servants all under the rule of this dominant male. Now it is used more generally "to refer to male domination, to the power relationships by which men dominate women, and to characterise a system whereby women are kept subordinate in a number of ways" (Bhasin 2006:3).

Patriarchy refers to the male domination both in public and private spheres. Feminists mainly use the term 'patriarchy' to describe the power relationship between men and women. Thus, patriarchy is more than just a term; feminists use it like a concept, and like all other concepts it is a tool to help us understand women's realities.

The concept of patriarchy is defined by different thinkers in different ways. Mitchell, a feminist psychologist, uses the word patriarchy "to refer to kinship systems in which men exchange women" (Mitchell 1971:24). Walby defines "patriarchy as a system of social structures and practices in which men dominate, oppress and exploit women" (Walby 1990:20). She explains patriarchy as a system because this helps us to reject the notion of biological determinism (which says that men and women are naturally 
different because of their biology or bodies and, are, therefore assigned different roles) or "the notion that every individual man is always in a dominant position and every woman in a subordinate one" (Ibid).

Patriarchy, in its wider definition, means the manifestation and institutionalization of male dominance over women and children in the family and the extension of male dominance over women in society in general. It implies that "men hold power in all the important institutions of society" and that "women are deprived of access to such power". However, it does not imply that "women are either totally powerless or totally deprived of rights, influence, and resources" (Lerner 1989:239).

Thus, patriarchy describes the institutionalized system of male dominance. So we can usefully define patriarchy as a set of social relations between men and women, which have a material base, and which, though hierarchical, establish or create independence and solidarity among men that enable them to dominate women (Jagger and Rosenberg 1984). Patriarchal ideology exaggerates biological differences between men and women, making certain that men always have the dominant, or masculine, roles and women always have the subordinate or feminine ones. This ideology is so powerful that "men are usually able to secure the apparent consent of the very women they oppress". They do this "through institutions such as the academy, the church, and the family, each of which justifies and reinforces women's subordination to men" (Millett 1977:35). The patriarchal system is characterized by power, dominance, hierarchy, and competition. So patriarchy is a system of social structures and practices in which men dominate, oppress and exploit women.

\section{Origin of Patriarchy}

Regarding the existence and origin of patriarchy, traditionalists do believe that men are born to dominate and women to be subordinate. They believe that this hierarchy has always existed and will continue, and like other rules of nature this one too cannot be changed. There are others who challenge these beliefs and say that patriarchy is not natural it is man-made and, therefore, it can be changed. 
In this regard, Aristotle propounded similar "theories" and called males active, females passive. For him female was "mutilated male", someone who does not have a soul. In his view, the biological inferiority of woman makes her inferior also in her capacities, her ability to reason and, therefore, her ability to make decisions. Because man is superior and woman inferior, he is born to rule and she to be ruled. He said "the courage of man is shown in commanding of a woman in obeying" (Learner 1989:8-11).

According to modern psychology, women's biology determines their psychology and, therefore, their abilities and roles. Sigmund Freud, for example, stated that for women anatomy is destiny. In his view, normal human was male (Freud 1977).

But these theories of male supremacy have been challenged and it has been proved that there is no historical or scientific evidence for such explanations. There are indeed biological differences between men and women but these distinctions do not have to become the basis of a sexual hierarchy in which men are dominant. The analysis of many of these theories enables us to recognise that patriarchy is man-made; historical processes have created it. No single explanation of the origin of patriarchy is accepted by all. Here, I will present only some of the principal theories put forward, and that too, very briefly.

A very important explanation for the origin of patriarchy was given by Frederick Engels in 1884 in his book, The Origins of the Family, Private Property and the State (Engels 1940). Engels believed that women's subordination began with the development of private property, when according to him, the world historical defeat of the female sex took place. He says both the division of classes and the subordination of women developed historically.

At that stage when private property arose in the society men wanted to retain power and property, and pass it on to their own children. To ensure this inheritance, mother-right was overthrown. In order to establish the right of the father, women had to be domesticated and confined and their sexuality regulated and controlled. According to Engels, it was in this period, both patriarchy and monogamy for women were established. 
According to the radical feminists (Brownmiller 1976, Firestone 1974), patriarchy preceded private property. They believe that the original and basic contradiction is between the sexes and not between economic classes. Radical feminists consider all women to be a class. Unlike the traditionalists, however, they do not believe that patriarchy is natural or that it has always existed and will continue to do so.

Socialist feminists accept and use the basic principles of Marxism but have tried to enrich and extend it by working on areas which, they believe, were neglected by conventional Marxist theory. They do not consider patriarchy to be a universal or unchanging system because of their commitment to a historical, materialist method as well as of their own observation of variety in the sexual division of labour. Socialist feminists view the struggle between women and men as changing historically with changes in modes of production (Beechey 1977).

Hartmann (1981) looks at the link between patriarchy and capitalism and argues that patriarchy links all men to each other irrespective of their class. A woman's work benefits both capital and her husband. Hartmann defines patriarchy as a set of relations which has a material base and in which there are hierarchical relations between men and solidarity among them, which in turn enable them to dominate women. The material base of patriarchy is men's control over women's labour power.

Another important 'socialist feminist view' has been presented by Mies (1988) in a paper entitled, The Social Origins of the Sexual Division of Labour. She puts forward some ideas regarding the possible reasons for and the sequence of historical developments leading to the origin of gender hierarchy or patriarchy. In this paper, she says, whatever the ideological differences between the various feminist groups, they are united in their rebellion against this hierarchical relationship between men and women, which is no longer accepted as biological destiny. Their enquiry into the social foundations of this inequality and asymmetry is the necessary consequence of their rebellion.

According to Mies, male-ness and female-ness are not biological givens, but rather the result of a long historical process. In each historic epoch male-ness and female-ness are differently 
defined, the definition depending on the principal mode of production in those epochs. This means that the organic differences between women and men are differently interpreted and valued, according to the dominant form of appropriation of natural matter for the satisfaction of human needs. According to Mies, women were the first producers of life, of social production, of the first tools of production and if they were also the first to initiate social relations, why were they unable to prevent the establishment of an hierarchical and exploitative relationship between the sexes? She answers this by saying that male supremacy, far from being a consequence of men's superior economic contribution, was a result of the development and control of destructive tools through which they controlled women, nature and other men.

According to Lerner (1989), patriarchy was not one event but a process developing over a period of almost 2500 years (from approximately $3100 \mathrm{BC}$ to $600 \mathrm{BC}$ ) and a number of factors and forces that were responsible for the establishment of male supremacy as we see it today. Gerda Lerner (1989), begins by emphasizing the importance of women history in women's struggle against patriarchy and for equality. According to her, patriarchy, in fact, preceded the formation of private property and class society.

One socialist feminist school of thought prefers to use the concept of subordination of women rather than patriarchy, which they reject as being historical. Patriarchy, according to them, is neither universal nor an all embracing phenomenon as different kinds of relationships have always existed between men and women in history. According to them, it is not sex but gender which is important; sex is biological, gender is social. This group is concerned with what they call gender relations (Oakley 1972).

The search for the social origins of this relationship is part

of the political strategy of women's emancipation. Without understanding the foundation and the functioning of the asymmetric relationship between men and women it is not possible to overcome it.

\section{Women's Subordination}

Patriarchy, which pre-supposes the natural superiority of male over female, shamelessly upholds women's dependence on, 
and subordination to, man in all spheres of life. Consequently, all the power and authority within the family, the society and the state remain entirely in the hands of men. So, due to patriarchy, women were deprived of their legal rights and opportunities patriarchal values restrict women's mobility, reject their freedom over themselves as well as their property.

Subordination means, "something else is less important than the other thing" (Cobuild 2010:1559). According to Advanced Learners Dictionary, "subordination means having less power or authority than somebody else in a group or an organization" (Hornby 2003:1296).

The term 'women's subordination' refers to the inferior position of women, their lack of access to resources and decision making etc. and to the patriarchal domination that women are subjected to in most societies. So, women's subordination means the inferior position of women to men. The feeling of powerlessness, discrimination and experience of limited self esteem and self-confidence jointly contribute to the subordination of women. Thus, women's subordination is a situation, where a power relationship exists and men dominate women. The subordination of women is a central feature of all structures of interpersonal domination, but feminists choose different locations and causes of subordination. Contemporary feminist theory begins with Simone de Beauvoir's argument that because men view women as fundamentally different from themselves, women are reduced to the status of the second sex and hence subordinate (Beauvior 1974). Kate Millet's theory of subordination argues that women are a dependent sex class under patriarchal domination (Millet 1977).

Patriarchy is a system whereby women are kept subordinate in a number of ways. The subordination that we experience at a daily level, regardless of the class we might belong to, takes various forms - discrimination, disregard, insult, control, exploitation, oppression, violence - within the family, at the place of work, in society. For instance, a few examples are illustrated here to represent a specific form of discrimination and a particular aspect of patriarchy. Such as, son preference, discrimination against girls in food distribution, burden of household work on women and young 
girls, lack of educational opportunities for girls, lack of freedom and mobility for girls, wife battering, male control over women and girls, sexual harassment at workplace, lack of inheritance or property rights for women, male control over women's bodies and sexuality, no control over fertility or reproductive rights.

So, the norms and practices that define women as inferior to men, impose controls on-them, are present everywhere in our families, social relations, religious, laws, schools, textbooks, media, factories, offices. Thus, patriarchy is called the sum of the kind of male domination we see around women all the time. In this ideology, men are superior to women and women are part of men's property, so women should be controlled by men and this produces women's subordination. In this context, Gerda Lerner in her book The Creation of Patriarchy said, "The use of the phrase subordination of women instead of the word "oppression" has distinct advantages. Subordination does not have the connotation of evil intent on the part of the dominant; it allows for the possibility of collusion between him and the subordinate. It includes the possibility of voluntary acceptance of subordinate status in exchange of protection and privilege, a condition which characterizes so much of the historical experience of women. I will use the term "paternalistic dominance" for this relation. "Subordination" encompasses other relations in addition to "paternalistic dominance" and has the additional advantage over "oppression" of being neutral as to the causes of subordination (Learner 1989:234-235).

Subordination is the situation in which one is forced to stay under the control of other. So women's subordination means the social situation in which women are forced to stay under the control of men. In this way to keep women under men's control, patriarchy operates some social customs, traditions and social roles by socialization process. To preserve the male supremacy, patriarchy created 'masculine' and 'feminine' characteristics, private-public realms by gendered socialization process. Socialization is considered to take place primarily during childhood, when boys and girls learn the appropriate behaviour for their sex. All agents of socialization process such as the family, religion, the legal system, the economic system and political system, the educational 
institutions and the media are the pillars of a patriarchal system and structure. The use of the term "social structure" is important here, since it clearly implies rejection both of biological determinism, and the notion that every individual man is in a dominant position and every women in a subordinate one. "In this system women's labour power, women's reproduction, women's sexuality, women's mobility and property and other economic resources - are under patriarchal control" (Walby 1990:20).

This control over and exploitation of areas of women's lives mean that men benefit materially from patriarchy, they derive concrete economic gains from the subordination of women. In what Walby calls the "patriarchal mode of production" (Ibid), women's labour is expropriated by their husbands and others who live there. She says housewives are the producing class, while husbands are the expropriating class, their back-breaking, endless and repetitive labour is not considered work at all and housewives are seen to be dependent on their husbands. So, there is a material basis for patriarchy. Most property and other productive resources are controlled by men and they pass from one man to another, usually from father to son. Even where women have the legal right to inherit such assets, a whole array of customary practices, emotional pressures, social sanctions and sometimes, plain violence, prevent them from acquitting actual control over them. In other cases, personal laws curtail their rights, rather than enhance them. In all cases, they are disadvantaged. So the material base of patriarchy, then, does not rest solely on child bearing in the family but on all the social structures that enable men to control women's labour.

Patriarchal ideology to keep women away the power systems has been attempted through the construction of private and public realms for women and men respectively. Theories of patriarchy by Walby shows "two distinct forms of patriarchy private and public patriarchy" (Walby 1990:24).

Private patriarchy is based upon household production as the main site of women's oppression. Public patriarchy is based principally in public sites such as employment and the state. The household does not cease to be a patriarchal structure in the public form, but it is no longer the chief site. In private patriarchy the 
expropriation of women's labour takes place primarily by individual patriarchs within the household, while in the public form it is a more collective appropriation. In private patriarchy the principle patriarchal strategy is exclusionary, in the public it is segregationist and subordinating. Above all, "the state has a systematic bias towards patriarchal interests in its policies and actions" (Walby 1990:21).

In this system, different kinds of violence may be used to control and subjugate women, such violence by men may even be considered legitimate and women are always routinely experienced by male violence. Male violence is systematically condoned and legitimated by the states refusal to intervene against it except in exceptional instance. Due to such violence (rape and other forms of sexual abuse, female foeticide, dowry murders, wife-beating) and the continued sense of insecurity that is instilled in women as a result keeps them bound to the home, economically exploited and socially suppressed.

In this patriarchal system, men and women behave, think, and aspire differently because they have been taught to think of masculinity and femininity in ways which condition difference. Patriarchal system shows in or accept that men have, or should have, one set of qualities and characteristics, and women another. Such as 'masculine' qualities (strength, bravery, fearlessness, dominance, competitiveness etc.) and 'feminine' qualities (caring, nurturing, love, timidity, obedience etc.).

Hartmann (1981) argues that both house work and wage labour are important sites of women's exploitation by men. Within the field of paid work occupational segregation is used by organized men to keep access to the best paid jobs for themselves at the expense of women. Within the household women do more labour than men, even if they also have paid employment (Hartmann, 1981a). These two forms of expropriation also act to reinforce each other, since women's disadvantaged position in paid work makes them vulnerable in making marriage arrangements, and their position in the family disadvantages them in paid work.

According to Lim (1997:220), patriarchy is the system of male domination and female subordination in economy, society and 
culture that has characterized much of human history to the present day. Patriarchal institutions and social relations are responsible for the inferior or secondary status of women in the capitalist wagelabour market. The primacy of the sexual division of labour within the family has several consequences for the women who seek wage employment.

\section{Patriarchal Structures in Bangladesh}

Discrimination against women constitutes a subordinate position of women and a violation of basic human rights and is an obstacle to the achievements of the objectives of women's equality, development and peace. In the last two decades, discrimination against women emerged as one of the most visible and articulated social issues in Bangladesh which generates women's subordination. Male domination and women's subordination are the basic tents of Bangladeshi social structure. All forms of discrimination constitutes the social, political, economical, religious and cultural differences between men and women and establish male dominated society. It also eliminates women's equality with men, forms women's subordination and constructs a social system which produce women's subordination.

The systems of patriarchy in Bangladesh are commonly identified by "patrilineal descent" (influence of patriarchy) and patrilocal residence (i.e. the practice of women living with their husband's relatives after marriage) (Rendall 1982:15-34). Patrilineal descent in Bangladesh is mainly organized along the patrilineal lines, "which has direct consequences to the position of women in the society" (Monsoor 1999:32). A boy is the perpetrator of the patriline, he will inherit the family name. On the other hand, a girl is treated as subordinate to men and of no or little value.

After marriage a girl goes to her husband's house. So our families think that girls are burden for them. Sons will earn and will look after their parents. So the oppression of a girl starts from her family. As a wife comes to her husband's house after marriage, so her husband thinks that she is in a subordinate position and he is more powerful than her. So, here a girl is also oppressed and discriminated. This experience of subordination destroys women's self-respect, self-confidence and self-esteem and sets limits on their 
aspirations.

Women's dependency upon and subordination to men is conditioned by a whole range of institutional practices embedded in the family and the Kin-group. It is these aspects which provide the constituent elements of the well-documented system of patriarchy in Bangladesh which institutionalizes the female subordination of women and their structured dependency on men.

Some examples of patriarchy in Bangladesh are as the following:

- In Bangladesh, people mostly prefer new born male children to female. When a woman gives birth to a girl her husband and other members of the family start to oppress and undermine her and the child.

a Discrimination against girls in the domestic menu, food distribution is still a common feature in maximum household. Probably for lack of food and care in Bangladesh maternal mortality rate is high.

a Burden of household work is mostly on the women and young girls, while men are executed on the plea of their economic activities. But patriarchal society like Bangladesh has no recognition to this work.

- Girls have to cope with lack of educational opportunities because their parents think education is primarily necessary for the male children. In patriarchal society, a woman from her childhood doesnot get equal chance with a boy to develop her qualities.

- Lack of freedom and mobility for girls is another main feature of patriarchy in Bangladesh. They can not go out to work, meet with their friends or come back any time, they have to return home before dusk.

a Wife battering is quite common in the country. Patriarchal norms that naturalize domestic violence are not freestanding, they are embedded in a larger culture of discipline. 
a Sexual harassment at workplace is another common feature. Many women workers are thrown out of their job when they are not willing to give in to the demands of their bosses.

a Women face discrimination of inheritance or property rights. In the Muslim families of Bangladesh sisters get half of their brothers' share while Hindu women get nothing. Only Christian women get equal share of property like-their brothers. But in this social structure of the patriarchal family women are deprived of their property rights which are granted.

a Male control over the female body or gross sexuality is a common feature.

- Women possess no control over fertility or reproductive rights. It is mostly the husbands who decide on family planning methods.

a In most cases, women have no rights to choose their husbands; rather the male members of their families impose decisions on them. After marriage, women are traditionally not allowed to provide support to their own relatives.

a In our patriarchal society, woman has to cover her self fully with cloth which is called purdah. We know the justification for purdah, beyond the Quranic verses on modesty which are clearly applicable to both sexes. But patriarchal structure operate this purdah on women's voice and movement to keep women in private place. Thus, purdah is a complex institution that entails much more than restrictions on women's physical mobility and dress.

It is observed that all practices and structures support women's subordination in practice which undermine women's position in Bangladesh. As Mahtab stated, in Bangladesh, women bear many of the marks of a "disadvantaged minority" in the social, economic and political realms. The traditional society of Bangladesh is permeated with patriarchal values and norms of female 
subordination, subservience, subjugation and segregation. The reality of the women of Bangladesh, (most specifically, the rural poor women and those living in the urban slums) is that they remain a vulnerable, marginalized group that is yet to enjoy equality in status, and access to services and resources with male counterparts. Women are found at the "bottom rung of poverty, illiteracy, and landlessness." (Mahtab 2007:20-21). Women are the most affected by negative impacts resulting from discrimination at birth leading to deprivation of access to all opportunities and benefits in family and societal life, such as education and health. This puts them in the most disadvantageous position and also the victims of worst forms of violence Some advancement of women does not prove that women are not subordinated. Though some changes have occurred, but such changes are marginal, superficial modifications in the ways in which men exploit women. Rather, male violence against women is systematically condoned and legitimated by the states' refusal to intervene against it except in exceptional instances, though the practices of rape, wife beating, sexual harassment etc. are too decentralized in their practice to be part of the state itself. However, patriarchy does not operate in a vacuum. Our normative social practices are deeply embedded in a disciplinary culture that condones or even encourages violence. Women's rights, under the Islamic law are often not implemented. There are lots of evidences, the rights which are grunted in the religious laws are often not enforced in a male dominated patriarchal society. Thus, the patriarchal argument that women are subordinated by religion is not completely true. Rather the proponents of patriarchy in the society use religion as a tool to conserve their dominance over females.

\section{Conclusion}

From the above discussion it is clear that in our country women are victims of subordination (e.g. under male domination), exploitation (e.g. unequal pay, low wages), oppression (e.g. violence). The issues of son preference, discrimination against girls (e.g. food distribution, burden of household work, lack of education, freedom and mobility), dowry, violence against women (e.g. wife-battering, rape), unequal wage, discriminatory personal laws, the use of religion to oppress women, the negative portrayal of women in the media, all of these patriarchal practices exist. 
Women in Bangladesh are apparently guaranteed gender equality by the constitution of Bangladesh and the general law. But patriarchal interpretation of the law continues the dominance of patriarchal attitudes. That is said the 'legal situation of Bangladeshi women is far better than the actual situation'. Legally women are not to be discriminated against in any sphere say in familial, social, political, economic and cultural life and specific legal provisions are to be in place to deal with any in infringement of the equal rights of women. Despite some recent reforms purporting to improve women's status, there is no real change in the situation of patriarchal domination. It is also argued that the dominant patriarchal structures, with the interlinked forces of religion, tradition and seclusion, are sustained not only in women's family life but also in every sphere of life. The main cause of women's subordination are the negative impact of tradition, religion, patriarchy, seclusion or purdah and paternalistic attitudes in the socio-economic and legal spheres. But among these factors patriarchy is the prime cause and other causes are the by-product of patriarchy. As because the main problem of subordination is not really religion or tradition, but patriarchal influence and authority, it is men who have interpreted religion, molding it perpetuate the patriarchal domination which has strong links with the issue of gender inequality.

Thus, to raise women's position, it is urgent to protect women from patriarchal subordination. It is patriarchal ideology which makes us feminine and masculine, which assigns different roles, rights and responsibilities to women and men. But those socalled 'masculine' and 'feminine' qualities are human qualities and not specific to either men or women. Since all works are done by both men and women, there is no reason to differentiate works on the basis of sex. Men made this differentiation of work only for their privilege, for their material benefit. Not every child in the family, just male child is allowed and encouraged to grow and flourish. So the culture which has been developed on the basis of gender should be changed. Family can play a great role by bringing a new dimension in reconstructing the ongoing socialization. Moreover, if men become more like women i.e. look after children and old people, run homes etc. It will make man more gentle, 
sensitive and human and will relieve women of some of the burden of work. And if bravery, fearlessness, rationality, efficiency are considered 'male' then women should definitely imbibe and practice these traits. Our double standards of morality and our laws, which give more rights to men should also be reformed. All that is needed is the recognition of justice and the courage to put an end to this injustice, male discrimination and double standard. Given the fact, that patriarchal oppression of women is rooted in the home/family sexuality, and man-woman relationship, so this patriarchal oppression and exploitation of women within families should be protected by "personal matter of families are addressed, analyzed to change.

Time has come to bring a radical change in the dominant ideology of patriarchy. This dominant ideology, which is produced from patriarchal structures is found in all areas of social relations. It is said that it is not enough to change only family value system, the laws of inheritance, property distribution, right over children should also be changed. To bring equality, it is essential to establish equal right between men and women in all respects of life. The responsibilities of women should also be equally distributed. In fact, I believe that real democracies and egalitarian societies can only be established if we practices democracy, equality and mutual respect within the family. Real peace in society can only be established if we experience peace at home.

\section{References}

Beauvior, D. S. 1974. The Second Sex. Vintage Books: New York.

Beechey, V. 1977. Some notes on female wage labour in capitalist production. Capital and Class. 3, autumn 45-66.

Bhasin, K. 2006. What Is Patriarchy. Women Unlimited: New Delhi.

Brownmiller, S. 1976. Against Our Will : men women and rape. Harmonds Worth: Penguin. 
Cobuild, C. 2010. Advanced Illustrated Dictionary. Harper Collins Publishers Ltd.: Great Britain.

Engels, F. 1940. The Origin of the Family, Private Property and the State. London : Lawrence and Wishart.

Firestone, S. 1974. The Dialectic of Sex : The case for feminist revolution. New York: Morrow.

Freud, S. 1977. On Sexuality. Harmondsworth : Penguin

Hartmann, H. 1. 1981. The Unhappy marriage of Marxism and Feminism: towards a more progressive union Women and Revolution, (ed). Lydia Sargent, London: Pluto Press., pp. 95-119.

1981a. The family as the locas of gender, Class and political struggle: the example of house work, Signs, 6, 3, pp. 366394.

Hornby A. S. 2003. Oxford Advanced Learner's Dictionary. Oxford University Press: New York.

Jagger, M. A. and Rosenberg S. P. (ed) 1984. Feminist Frameworks. New York : MC Grew-Hill.

Lerner, G. 1989. The Creation of Patriarchy. Oxford University Press: New York.

Lim, Y.C. Linda..1997. Capitalism, Imperialism and Patriarcy: The Dilemma of Third-World Women Workers in Multinational Factorie in Visvanathan, Naline (etal). The Women Gender and Development Reader. The University Press Limited: Dhaka. 215230.

Mahtab N. 2007. Women in Bangladesh from Inequality to Empowerment. A H Development Publishing House: Dhaka.

Mies M. (etal) 1988. Women: The Last Colony. Delhi : Kali for Women.

Millett, K. 1977. Sexual Politics. London: Virago.

Mitchell, J. 1971. Women's Estate. Harmondsworth: Penguin.

Monsoor, T. 1999. From Patriarchy to Gender Equity : Family law and its Impact on Women in Bangladesh. The University Press Limited: Dhaka. 
Oakley, A. 1972. Sex Gender and Society. London: Temple Smith. Rendall, V. 1982. Women in Politics. London.

Walby, S. 1990. Theorizing Patriarchy. Blackwell Publishers Ltd.: Oxford, UK and Cambridge USA. 